\title{
Pembatalan Perjanjian Sewa Gedung Pernikahan Akibat Pandemi Covid-19
}

\author{
Septini Anriwati ${ }^{1}$, Dwi Aryanti Ramadhani² \\ Fakultas Hukum, Universitas Pembangunan Nasional Veteran Jakarta \\ Correspondence email: septinianriwati@upnvj.ac.id, dwiaryanti@upnvj.ac.id
}

\begin{abstract}
Abstrak. Perjanjian/perjanjian merupakan hubungan hukum yang sering dilakukan dalam dunia usaha/masyarakat di Indonesia. Dengan di keluarkannya Keppres yang menetapkan Virus Corona (COVID19) Sebagai bencana nasional telah berdampak pada segala aspek kehidupan masyarakat kemudian pemerintah daerah mengeluarkan peraturan daerah pembatasan sosial berskala besar (PSBB). Dengan diputuskannya Covid-19 sebagai darurat bencana nasional menyebabkan berlakunya pembatasan dan/atau larangan untuk berkegiatan pada masyarakat, yang berakibat pada terjadinya pembatalan pada perjanjian sewa-menyewa gedung untuk resepsi pernikahan yang dapat mengakibatkan terjadinya wanprestasi pada pemenuhan hak kewajiban Para Pihak. Penelitian dilakukan dengan metode yuridis normatif dan spesifikasinya menggunakan deskriptif analitis. metode penelitian yang metode penelitian yang menggunakan pendekatan yang dilakukan berdasarkan bahan hukum utama dengan cara menelaah teori-teori, konsep-konsep, asas-asas hukum serta peraturan perundang-undangan yang berhubungan dengan penelitian ini. Hasil penelitian dan pembahasan menunjukan bahwa Covid-19 dapat dikategorikan sebagai kondisi Kahar (force majeuer) yang dapat menjadi alasan pada pembatalan suatu perjanjia sewa menyewa gedung. Sehingga diperlukan suatu renegosiasi guna untuk pemenuhan kewajiban para Pihak dalam sewa menyewa gedung.
\end{abstract}

Kata Kunci: Perjanjian; Sewa menyewa; Covid-19; Pembatalan

\begin{abstract}
Agreement / contract is a legal relationship that is often carried out in the business world / community in Indonesia. With the issuance of the Presidential Decree which stipulates the Corona Virus (COVID19) as a national disaster it has had an impact on all aspects of community life then the local government issued a large-scale social restriction (PSBB) regional regulation. With the decision of Covid-19 as a national disaster emergency, restrictions and / or restrictions on activities in the community were imposed, which resulted in the cancellation of the building lease agreement for wedding receptions which could result in default in fulfilling the rights of the Parties. The research was conducted by using the normative juridical method and the specification using descriptive analytical. research methods that are research methods that use an approach based on the main legal materials by examining theories, concepts, legal principles and laws and regulations related to this research. The results of the research and discussion show that Covid-19 can be categorized as a force majeure which can be a reason for the cancellation of an agreement to rent a building. So that a renegotiation is needed in order to fulfill the obligations of the Parties in leasing a building.
\end{abstract}

Keywords: Agreement; Rent; Covid-19; Cancellation

\section{PENDAHULUAN}

Kini seluruh dunia sedang marak dengan virus corona atau Coronavirus Disease 2019 yang kini disebut dengan Covid-19, virus tersebut sudah menyebar kebanyak negara didunia. Dan kini Covid-19 sudah menjadi pandemik di dunia, tidak terkecuali di Indonesia.

Setelah World Health Organitation (WHO) mengungkapkan bahwa covid-19 ini menjadi pandemik dunia, Presiden Republik Indonesia Joko Widodo akhirnya menyatakan penyebaran wabah yang membahayakan ini sebagai bencana nasional. Kondisi darurat akan diberlakukan sejak 13 April 2020. Selanjutnya, Presiden Republik Indonesia membuat Keputusan Presiden (Keppres) No. 12 Tahun 2020 tentang Penetapan Bencana Non-Alam Penyebaran Corona Virus Disease 2019 (Covid-19) Sebagai Bencana Nasional. ${ }^{1}$

Pemerintah telah mengambil langkah-langkah untuk mengatasi situasi khusus tersebut, yaitu dengan menerapkan "Social Distancing". Motif tersebut menunjukkan maka untuk meredam atau bahkan memutuskan rantai penularan Covid-19, seseorang harus menjaga jarak aman minimal 2 meter dari orang lain, serta tidak disarankan untuk menyelenggarakan kontak langsung dengan orang lain untuk menghindari pertemuan massal. ${ }^{2}$

Dalam Keppres Nomor 12 Tahun 2020 Bencana Non-Alam Penyebaran Corona Virus Disease 2019 (Covid-19) ini menetapkan bahwa Gubernur, bupati, dan walikota sebagai Ketua Gugus Tugas Percepatan Penanganan: Covid-I9 di daerah dapat membuat kebijakan mengenai aturan penanggulangan Covid-19 untuk daerahnya masing-masing tetapi dalam mengesahkan kebijakan pada daerah masing-masing wajib memperhatikan kebijakan Pemerintah Pusat ${ }^{3}$.

\footnotetext{
${ }^{1}$ https://www.hukumonline.com/berita/baca/lt5e947d66e1254/penyebaran-covid-19-ditetapkan-sebagai-bencana-nasional/

2 D.R,Buana), 'Analisis Perilaku Masyarakat Indonesia dalam Mengha dapi Pandemi Virus Corona (Covid-19) dan Kiat Menjaga Kesejahteraan Jiwa', salam jurnal sosial dan budaya Syar'I, Vol.7, no.3. hlm. 218 . 2020

${ }^{3}$ Keputusan Presiden Nomor 12 Tahun 2020 Tentang Penetapan Bencana Non-Alam Penyebaran Corona Virus Disease 2019 (Covid-19) Sebagai Bencana Nasional
} 
Dengan adanya Keppres No.12 Tahun 2020 membuat beberapa Pemerintah Daerah membuat kebijakan mengenai Pemberlakuan Sosial Berskala Besar (PSBB) salah satu nya yaitu pada daerah Jawa Barat yang tertuang dalam Peraturan Gubernur Jawa Barat Nomor 36 Tahun 2020 Tentang Pedoman Pembatasan Sosial Berskala Besar Dalam Penanggulangan Coronavirus Disease 2019 (Covid-19) Di Wilayah Provinsi Jawa Barat, dalam kebijakan Peraturan Gubernur Jawa Barat menerangkan bahwa segala kegiatan dilakukan dirumah kecuali untuk beberapa sektor.

Dalam pelaksanaan resepsi pernikahan pada pasal 15 ayat (3) dalam Peraturan Gubernur Jawa Barat No.36 Tahun 2020 mengatur bahwa pernikahan tetap dapat dilakukan namun hanya pada Kantor Urusan Agama (KUA) dan catatan sipil serta tidak diperbolehkannya untuk membuat acara resepsi yang dapat mengundang keramaian, ${ }^{4}$ tetapi di sisi lain, segala rencana resepsi pernikah tentunya sudah disiapkan dari jauh-jauh hari. Pasangan yang akan melakukan pernikahan akan menjalin kerjasama dengan banyak pihak, salah satunya dengan menyewa sebuah tempat untuk resepsi. Hal tersebut tentunya butuh kerjasama, yang pada umumnya akan dituangkan dalam perjanjian dengan waktu tertentu

Selama pandemi covid-19 ini, menyebabkan perjanjian yang memuat penyewaan Gedung untuk mengadakan resepsi pernikahan dalam kurun waktu telah ditetapkan sebagai status darurat bencana, menjadi tertunda atau sama sekali dibatalkan, salah satunya pada sebuah gedung $M \& R$ di daerah Bekasi, pengantin terpaksa membatalkan acara resepsi pernikahan karena adanya aturan tentang PSBB tersebut untuk menghindari kerumunan. ${ }^{5}$ hal ini menjadi dampak yang besar bagi para keluarga pengantin yang telah mempersiapakan segala rangkaian acara resepsi pernikahan.

Akibat adanya pembatalan tersebut mengakibatkan segala rencana yang telah disiapkan menjadi batal atau diundu dan pihak yang telah mengikatkan diri dalam penyewaan gedung $M \& R$ terpaksa harus dibatalkan atau pelaksanaan resepsi tersebut harus diundur hingga waktu yang tidak dapat ditentukan, dengan adanya pembatalan tersebut membuat kerugian berupa pengembalian DP (Down Payment) yang tidak dapat dikembalikan seluruhnya.

Hal ini akan menjadi efek yang berkelanjutan. Bukan hanya perjanjian penyewaan gedung untuk mengadakan pernikahan selama masa pandemi corona ini saja yang akan di tunda atau dibatalkan, namun setelah masa ini pun akan mengundurkan waktu pelaksanaan perjanjian penyewaaan gedung lainnya yang sudah ada kesepakatan para pihak. Pada perjanjian sewa, pihak yang terikat yaitu pihak yang menyewakan dan pihak penyewa. Pihak yang menyewakan dapat berbentuk orang atau badan hukum yang menyewakan barang atau benda kepada pihak untuk menikmati kegunaan benda tersebut bagi penyewa. Pihak yang menyewakan barang atau barang tidak harus pemilik barang, tetapi semua orang yang mengalihkan hak penggunaan barang kepada orang lain atas dasar penguasaan. Pada sewamenyewa, yang diberikan untuk pihak penyewa tidaklah hak kepemilikan atas barang tersebut, tetapi penggunaan atau pengumpulan atas hasil barang telah disewakan. ${ }^{6}$

Sedangkan segala hal yang sudah tercantum dalam perjanjian haruslah dilaksanakan sepenuhnya oleh para pihak yang mengikat seperti Undang-undang.

Dalam Undang-undang Nomor 4 tahun 1984 Tentang Wabah Penyakit Menular dalam Pasal 1 huruf (a) menjelaskan "Wabah penyakit menular yang selanjutnya disebut wabah adalah kejadian berjangkitnya suatu penyakit menular dalam masyarakat yang jumlah penderitanya meningkat secara nyata melebihi dari pada keadaan yang lazim

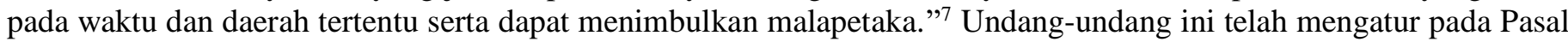
5 ayat (1) huruf "dalam penanggulangan wabah penyakit menular dapat dilaksanakan dengan pemeriksaan, pengobatan, perawatan, dan isolasi penderita, termasuk tindakan karantina; pencegahan dan pengebalan; pemusnahan penyebab penyakit";; dan pada Pasal 6 ayat (2) ditegaskan "dalam hal tata cara upaya penanggulangan wabah penyakit ini diatur dengan peraturan pemerintah". 9

Namun dengan adanya pandemi covid-19 ini membuat beberapa perjanjian harus tertunda bahkan dibatalkan sebab World Health Organization (WHO) telah menetapkan covid-19 sebagai pandemi global serta Presiden Republik Indonesia dalam Keppres No.12 Tahun 2020 tentang penetapan bencana non-alam penyebaran covid-19 sebagai bencana nasional disebabkan karena penularan covid-19 ini telah berakibat melonjaknya jumlah korban dan kerugian harta benda, Memperluas cakupan wilayah yang terkena bencana dan berdampak pada aspek sosial ekonomi Indonesia

${ }^{4}$ Pasal 15 ayat (3) Peraturan Gubernur Jawa Barat Nomor 36 Tahun 2020 Tentang Pedoman Pembatasan Sosial Berskala Besar Dalam Penanggulangan Coronavirus Disease 2019 (Covid-19) Di Wilayah Provinsi Jawa Barat

${ }^{5}$ Marcel Mariana (2020), Batal Resepsi Karena Wabah Virus Corona Pasangan Ini Bagi-bagi Makanan Catering Ke anak Yatim-Kami Ingin Semua Sehat Walafiat https://sajiansedap.grid.id/read/102071598/batal-resepsi-karena-wabah-virus-coronapasangan-ini-bagi-bagi-makanan-catering-ke-anak-yatim-kami-ingin-semua-seha t-walafiat

6 Ramadhani,D.,Wien Sukarmini,dan Yuliana Yuli. "Pelatihan Membuat Surat Perjanjian Sewa-Menyewa Rumah Perjanjianan Di Kelurahan Tugu", Kota Depok, Jawa Barat, Fakultas Hukum, Universitas Pembangunan Nasional Veteran Jakarta, Hal.245.2019

${ }^{7}$ Undang-undang Nomor 4 tahun 1984 tentang wabah penyakit menular

${ }^{8}$ Ibid Pasal 5 ayat (1)

${ }^{9}$ Ibid Pasal 6 ayat (2) 
yang luas. Menurut Teori Perjanjian yang dikemukakan oleh Subekti "Suatu perjanjian dinamakan juga persetujuan karena kedua pihak itu setuju untuk melakukan sesuatu, dapat dikatakan bahwa dua perkataan (perjanjian dan persetujuan) itu adalah sama artinya" 10

Berdasarkan latar belakang diatas, maka permasalahan yang hendak diangkat dalam penulisan jurnal ini adalah Apakah Pandemi Covid-19 dapat menjadi alasan pembatalan sewa gedung pernikahan Serta Bagaimana pemenuhan hak dan kewajiban para pihak akibat pembatalan perjanjian sewa gedung pernikahan dimasa pandemi covid-19.

\section{METODE \\ Jenis Penelitian}

Jenis Penelitian yang akan digunakan oleh penulis dalam artikel jurnal ini adalah Jenis Penelitian Yuridis Normatif yaitu metode penelitian yang menggunakan pendekatan yang dilakukan berdasarkan bahan hukum utama dengan cara menelaah teori-teori, konsep-konsep, asas-asas hukum serta peraturan perundang-undangan yang berhubungan dengan penelitian ini. Pendekatan masalah yang akan digunakan penulis dalam artikel jurnal ini adalah pendektaan kasus (case approuach) yaitu penulis meneliti dengan mencoba membangun argumentasi hukum dalam perspektif kasus konkrit yang terjadi dilapangan.

\section{Jenis Pengumpulan data}

Cara pengumpulan daya yang digunakan penulis untuk melakukan penelitian yaitu dengan cara kepustakaan (LibraryResearch) yaitu dengan mengkaji beberapa artikel dan peraturan perundang-undangan dalam menyelesaikan sebuah kasus yang sedang terjadi dilapangan.

\section{HASIL DAN PEMBAHASAN \\ Pandemi Covid-19 Dapat Menjadi Alasan Pembatalan Perjanjian Sewa Gedung Pernikahan}

Berdasarkan dengan Pasal 1265 KUHP dijelaskan "Suatu syarat batal adalah syarat yang bila dipenuhi akan mengha puskan perikatan dan membawa segala sesuatu kembali pada keadaan semula, seolah-olah tidak pernah ada suatu perikatan. Syarat ini tidak menunda pemenuhan perikatan; ia hanya mewajibkan kreditur mengembalikan apa yang telah diterimanya, bila peristiwa yang dimaksudkan terjadi". ${ }^{11}$ Kondisi yang harus di jelaskan sebagai syarat batal adalah terdapat suatu pelanggaran perjanjian, dalam hal ini pelanggaran selalu dianggap sebagai kondisi yang tidak sah dalam sebuah perjanjian, hingga pihak yang dirugikan oleh pelanggaran pihak lain dapat meminta pembatalan perjanjian tersebut. ${ }^{12}$

Kondisi ini dapat dilaksanakan dengan dua cara, baik secara positif, yaitu secara langsung meminta pembatalan di hadapan hakim, atau melalui pembelaan, yaitu menunggu kesepakatan di hadapan hakim sebelum dituntut, kemudian memberikan alasan atas tidak adanya kesepakatan. ${ }^{13}$

Adapula penyebab yang mempengaruhi batal/berakhirnya suatu Perjanjian yaitu:

1. perjanjian tersebut batal dengan adanya kesepakatan oleh para pihak

2. Yang menjadi Objek perjanjian tersebut telah habis/lunas

3. salah satu pihak tidak memenuhi prestasinya

4. adanya putusan pengadilan menetapkan bahwa perjanjian telah berakhir

5. Perjanjian tersebut dianggap batal demi hukum ${ }^{14}$

Dalam perjanjian sewa gedung pada gedung resepsi pernikahan yang telah dibuat dalam jauh-jauh hari mewajibkan penyewa dan pemilik gedung harus melaksanakan hak dan kewajiban yang telah disepakati tersebut. Dalam kesepakatan perjanjian sewa terkadang pemilik gedung tidak dapat melaksanakan prestasinya. Dengan mempertimbangkan syarat-syarat kesepakatan yang dicapai para pihak kegagalan ini bisa dikatakan sebagai ingkar janji atau keadaan kahar. Jika termasuk pelanggaran perjanjian, penyewa dapat menuntut ganti rugi dari pemilik gedung yang lalai. Sementara itu, jika terjadi keadaan kahar, pemilik gedung yang tidak melakukan prestasi dapat dibebaskan dari ganti rugi. ${ }^{15}$

Orang yang dituduh lalai pada pelaksanaan perjanjian dapat memberikan pembelaan dengan alasan:

${ }^{10}$ Suharnoko,SH.,M.L.I, Hukum Perjanjian: Teori dan Analisa Kasus (Jakarta : Kencana), Hlm. 3.2017

${ }^{11}$ Pasal 1265 KUHPerdata

12 Dewitasari, Y., \& Tuni, P. Akibat Hukum Terha dap Para Pihak dalam Perjanjian Apabila Terjadi Pembatalan Perjanjian. Fakultas Hukum Universitas Udayana.hlm 3.2011

${ }^{13}$ P.N.H. Simanjuntak, 2007, Pokok-pokok Hukum Perdata Indonesia, Djambatan, Jakarta, hlm.347.2007

14 Adriansyah (2020), "Pembatalan Perjanjian Karena Pandemi Covid-19 Keadaan kahar “ https://www.propertynbank.com/pembatalan-perjanjian-karena-pandemi-covid-19-force-majeure/

15 Agri Chairunisa Isradjuningtias,(2016) Jurnal: Force Mejerure (Overmacht) dalam Hukum Perjanjian (Perjanjian) Indonesia, Fakultas Hukum Universitas Katholik Parahyangan, h.147. 
1. Mengajukan gugatan bahwa terdapat keadaan kahar

2. Mengajukan bahwa si berpiutang (kreditur) juga telah lalai

3. Mengajukan bahwa kreditur telah melepaskan hak nya untuk menuntut ganti rugi ${ }^{16}$

Faktor yang menghambat pemilik gedung menjalankan prestasinya karena timbulnya pandemi Covid-19 sebagaimana telah diterangkan sebelumnya bahwa pemerintah telah menetapkannya sebagai bencana nasional berdasarkan Keppres No.12 Tahun 2020 Tentang gugus Tugas Percepatan Penanganan Corona Virus Disease 2019 (COVID-19). Hal ini menjadi masalah dalam pelaksanaan perjanjian sewa gedung pernikahan yang tidak dapat dilakukan akibat adanya pandemi Covid-19. Sebagian daerah menjalankan karantina secara ketat kemudian akses keluar-masuk yang dibatasi serta penutupan beberapa tempat usaha karena himbauan untuk melakukan segala kegiatan di rumah. Serta keluarnya peraturan gubernur yang melarang untuk melakukan resepsi pernikahan karena akan mengundang keramaian. Maka pandemi virus ini tidak dapat diketahui akan terjadi. Namun dalam perjanjian tersebut tidak menjelaskan mengenai pembatalan akibat adanya pandemi ini sebab pandemi COVID-19 tidak tercantum dalam klausul keadaan kahar.

Nampaknya kemampuan pemilik gedung harus benar-benar diperhatikan untuk melihat kejadian yang tergolong default atau keadaan kahar. Jika pemilik gedung seharusnya dapat melaksanakan tugasnya, namun pemilik gedung tidak dapat melaksanakan tugasnya, maka dapat diklasifikasikan sebagai ingkar janji. Tetapi apabila pemilik gedung berhalangan melaksanakan tugasnya karena kejadian diluar kemampuan pemilik gedung, maka diklasifikasikan sebagai keadaan kahar $^{17}$

Covid-19 dapat tergolong sebagai keadaan kahar bukan ingkar janji. Jika ditinjau lebih lanjut, terdapat faktor kelalaian pada pemilik gedung dalam pelaksanaan prestasi tersebut tidak terpenuhi. ${ }^{18}$ Alasan pertama adalah pelanggaran perjanjian terjadi karena pemilik gedung dengan sengaja tidak memenuhi kewajibannya. Entah sama sekali tidak mampu mencapai pencapaiannya sendiri, atau pencapaian pemilik gedung tidak sesuai dengan kesepakatan, pemilik gedung sudah lama tidak dapat meraih pencapaiannya sendiri, atau melakukan hal-hal yang dilarang oleh isi perjanjian. Alasan kedua, meski pandemi virus bukanlah hal baru, namun pandemi virus corona Covid-19 jelas berada diluar kendali internasional. Terlihat dari pengaruhnya yang sangat besar terhadap sektor ekonomi yang juga berada di luar kendali negara Indonesia. ${ }^{19}$

Kondisi keadaan kahar mengacu pada kondisi yang menyebabkan salah satu pihak tidak bisa melakukan kewajiban ataupun haknya tanpa menejelaskan faktor hukum kepada pihak lain untuk menuntut atau meminta pihak yang tidak dapat melaksanakan kewajibannya, karena keadaan kahar melebihi kekuasaan atau kemampuan pihak lain untuk melaksanakan kewajibannya.

Pada Pasal 1244 KUHPerdata menjelaskan "Pemilik gedung harus dihukum untuk mengganti biaya, kerugian dan bunga bila ia tak dapat membuktikan bahwa tidak dilaksanakannya perikatan itu atau tidak tepatnya waktu dalam melaksanakan perikatan itu disebabkan oleh sesuatu hal yang tak terduga, yang tak dapat dipertanggungkan kepadanya walaupun tidak ada itikad buruk kepadanya". Serta ditekankan pula dalam Pasal 1245 KUHPerdata bahwa "Tidak ada penggantian biaya, kerugian dan bunga bila karena keadaan memaksa atau karena hal yang terjadi secara kebetulan, pemilik gedung terhalang untuk memberikan atau berbuat sesuatu yang diwajibkan, atau melakukan suatu perbuatan yang terlarang baginya"

Hal penting untuk mempelajari beberapa elemen dasar untuk dapat menetapkan bahwa Covid-19 merupakan bencana nasional yang dapat di golongkan sebagai keadaan kahar, yaitu:

1. terdapat klausul keadaan kahar dalam perjanjian ;

2. makna dan batas keadaan kahar yang disepakati pemilik gedung dan penyewa dalam perjanjian sewa-menyewa gedung M\&R;

3. Adanya hubungan sebab-akibat antara penegasan COVID-19 sebagai bencana nasional dan implementasi kesepakatan;

4. Salah satu pihak mengungkapkan ketulusan dan akan menyatakan keadaan memaksa atau keadaan kahar ${ }^{20}$

16 Budiman N.P.D S, "Hukum Perjanjian \& Penyelesaian Sengketa Dari Perspektif Sekretaris",(Jakarta : PT RAJAGRAFINDO PERSADA) hlm.25.2005

17 Hero Pandi, Penyelesaian Ganti Rugi Karena Force Mejeure Dalam Kasus Jasa Pengangkutan, Fakultas Hukum Universitas Islam Malang, hlm. 7. 2019

18 Wafa, K., Suseno, I., \& Prasetyawati, E. Klausa Keadaan Kahar Dalam Perjanjian Dan Pandemi Covid-19 Di Indonesia. Maleo Law Journal, 4(2) hlm.169.2020

${ }^{19}$ Ibid

${ }^{20}$ Kaya, P. B. T. A., \& Dharmawan, N. K. S. Kajian Keadaan kahar Terkait Pemenuhan Prestasi Perjanjian Komersial Pasca Penetapan Covid-19 Sebagai Bencana Nasional. Kertha Semaya: Journal Ilmu Hukum, 8(6),.hlm. 896.2020 
Pembatalan suatu perjanjian sewa dalam gedung pernikahan yang di batalkan dengan alasan adanya pandemi covid-19 tidak serta merta dapat dikatakan sebagai alasan keadaan kahar. Mengenai penetapan COVID-19 sebagai bencana nasional, apakah terdapat kausalitas pada implementasi kesepakatan penting untuk melakukan penelitian guna menentukan keadaan keadaan kahar, yang sama dengan membuktikan bahwa "peristiwa yang tidak diharapkan menyebabkan pihak tersebut tidak dapat melaksanakan kewajibannya. Elemen ini terkait saat menentukan keberadaan kausalitas, penting untuk menentukan sejauh mana kesepakatan tidak dapat dilaksanakan, dan apakah realisasi kesepakatan secara keseluruhan tidak mungkin atau hanya sebagian. Ini juga penting untuk menentukan konsekuensi apa yang dapat dikenakan oleh para pihak. ${ }^{21}$

Pandemi COVID-19 bisa digolongkan sebagai keadaan kahar yang bersifat sementara, karena jika dilihat pandemi ini terjadi dalam kurun waktu tertentu. Pandemi COVID-19 tidak serta merta menjelaskan alasan para pihak membatalkan perjanjian dengan alasan keadaan kahar, sehingga tidak bisa dianggap perjanjian ini tidak bisa dilaksanakan begitu saja. ${ }^{22}$

Keadaan kahar terbagi dalam dua macam, yaitu keadaan kahar yang bersifat absolut dan keadaan kahar yang bersifat relatif, yang mana keduanya mempunyai faktor berbeda. Keadaan kahar yang bersifat absolut adalah Kondisi yang meyakinkan untuk pencapaian tidak dapat dicapai. Kesepakatan tersebut tak dapat tercapai karena suatu hal yang tidak dapat lagi dicapai dari satu pihak (seperti bencana alam atau kecelakaan yang berdampak langsung pada pada objek perjanjian yang disepakati kedua belah pihak). ${ }^{23}$ Serta keadaan memaksa yang bersifat relatif (sementara) Merupakan kondisi dimana pemilik gedung dapat melaksanakan kewajibannya di lain waktu. ${ }^{24}$

Berdasarkan uraian unsur-unsur keadaan kahar di atas, dapat dikatakan bahwa pandemi Covid-19 tergolong keadaan kahar. Artinya, beberapa pemilik gedung memang terhalang, namun ada pula yang tidak terhalang untuk memenuhi kewajiban perjanjiantualnya

Konsekuensi hukum dari pandemi sebagai keadaan kahar adalah para pihak tidak dapat menggunakan pandemi sebagai alasan untuk membatalkan perjanjian keadaan kahar yang bersifat sementara hanya dapat menangguhkan sementara atau menangguhkan kewajiban perjanjian pemilik gedung, tetapi tidak dapat membatalkan perjanjian. ${ }^{25}$ Perjanjian tersebut masih berlaku dan mengikat kedua belah pihak. Terjadinya pandemi Covid-19 hanya menunda pemenuhan kewajiban si penyewa gedung pernikahan tersebut kepada yang menyewa, dan tidak sepenuhnya menghilangkan kewajiban pemilik gedung kepada kreditor.

\section{Pemenuhan Hak dan Kewajiban Para Pihak Akibat Pembatalan Perjanjian Sewa Gedung Pernikahan Dimasa Pandemi Covid-19}

Perjanjian atau yang seringpula disebut dengan perjanjian menurut Pasal 1313 KUH Perdata adalah "perbuatan yang mana satu orang/lebih saling mengikatkan dirinya terhadap satu orang/lebih. Dari peristiwa ini timbulah akibat hukum antara dua orang/lebih yang disebut perikatan yang didalamnya terdapat hak dan kewajiban masing-masing pihak."

Perjanjian sewa menyewa pada biasanya disebut sebagai perjanjian konsensuil, yaitu perjanjian yang dibentuk bagi pihak yang menyewakan dengan pihak penyewa telah mencapai kesepakatan terutama pada unsur pokok yaitu barang / harga. Selain itu juga meliputi sifat yang harus diupayakan dari masing-masing pihak yang terlibat dalam perjanjian tersebut, dari pihak pemilik tentu akan menuntut terpenuhinya persyaratan-persyaratan maupun kewajibankewajiban yang diajukan. ${ }^{26}$

Dalam perjanjian sewa-menyewa pemilik gedung hanya menyerahkan penggunaan gedung dan pemungutan hasil dari sewa gedung tersebut yang disewakan, sedangkan hak kepemilikan tetap menjadi hak pemilik gedung M\&R Tersebut. ${ }^{27}$ Sesuai ketentuan Pasal 1550 KUHPerdata, pihak yang menyewakan memilik tiga kewajiban yang harus dipenuhi, yaitu:

1. Menyerahkan barang yang disewakan kepada penyewa; 28

${ }^{21}$ Ibid hlm 897

${ }^{22}$ Op.cit Wafa K,Dkk hlm. 170

${ }^{23}$ Wibawa, P. P. A., \& Artadi, I. K. "Akibat hukum terha dap pemilik gedung atas terjadinya force majeure (keadaan memaksa).’Kertha Semaya: Journal Ilmu Hukum 2 No.6:hlm.5

${ }^{24}$ Muljono, B. E., \& Sastradinata, D. N. Keabsah n Keadaan kahar Dalam Perjanjian Di Masa Era Pandemi Covid19. Jurnal Humaniora: Jurnal Ilmu Sosial, Ekonomi dan Hukum, 4(2),hlm.261.2020

${ }^{25}$ Dona B.K “ Pandemi Covid-19 Apakah Keadaan kahar?”, Jurnal Rechts Vinding : Media Pembinaan Hukum Nasional. HIm 3.2020

26 Sani, A “Tanggung Jawab Para Pihak Dalam Pelaksanaan Perjanjian Sewa Menyewa Mobil Pada Cv Mutiara Transportation Di Kota” TEGAL (Doctoral dissertation, Program Pasca Sarjana Universitas Diponegoro).hlm.2.2005

27 Augustinus S, "HUKUM BISNIS: Sebuah Pemahaman Integratif antara Hukum dan Praktik Bisnis", Depok : PT RAJAGRAFINDO PERSADA hlm.91.2018

${ }^{28}$ Pasal 1550 ayat (1) KUHPerdata 
Yang diserahkan hanyalah penguasaan bendanya saja melainkan bukan hak miliknya. Dalam pasal 1550 KUHPerdata dijelaskan bahwa "barang yang disewakan oleh pihak yang menyewakan harus diberikan atau diserahkan dalam keadaan baik dan tidak ada kerusakan. Pihak yang menyewakan tersebut harus melakukan perbaikan terhadap benda sewaan." 29

2. Memelihara barang itu sedemikian rupa sehingga dapat dipakai untuk keperluan yang dimaksud; ${ }^{30}$ yaitu bertujuan untuk pemeliharaan keselamatan, keamanan, dan kenikmatan berlangsungnya masa sewa, maka jika terdapat perbaikan terhadap benda sewaan tidak menggangung kenikmatan penyewa melainkan memberikan ketentraman kepada penyewa saat menggunakan barang sewaan tersebut. ${ }^{31}$

3. Memberikan hak kepada penyewa untuk menikmati barang yang disewakan itu dengan tenteram selama berlangsungnya sewa ${ }^{32}$. Pihak yang menyewakan harus menjamin bahwa barang yang disewakan dapat dipakai dan digunakan dengan aman oleh pihak penyewa selama pemberlakuan masa sewa.

Kemudian kewajiban bagi penyewa adalah :

1. Menggunakan barang yang telah di sewa olehnya dengan baik tanpa merusak fasilitas apapun sesuai dengan tujuan yang telah diberikan pada benda sewaan tersebut sesuai dengan perjanjian sewa nya

2. Membayar uang sewa sesuai dengan waktu yang telah disetujui oleh para pihak dalam perjanjian sewa-menyewa nya.

3. Mengganti kerugian apabila saat menggunakan barang yang disewakan tersebut terjadi kerusakan yang diakibatkan oleh penyewa atau kesalahan orang yang berada di dalamnya seperti pada gedung resepsi pernikahan yang terdapat tamu-tamu undangan.

4. Mengembalikan barang yang disewa atau menggunakan barang sewaan sesuai dengan waktu yang telah disepakati oleh para pihak sesuai dengan yang tertuan dalam perjanjian sewa-menyewa tersebut.

5. Tidak boleh menyewakan kembali barang sewaan tersebut kepada orang lain, jika ketentuan tersebut ada kemudian dilanggar maka perjanjian tersebut dapat du bubarkan dan penyewa dapat dituntut dengan memberikan ganti kerugian atau bunga uang tersebut. ${ }^{33}$

Dalam gedung penggelar resepsi pernikahan pada gedung M\&R hak dan kewajibannya sama dengan yang telah diatur oleh pasal 1550 KUHPerdata. Namun gedung tersebut telah membuat suatu klausul pembatalan saat para pihak menyetujui untuk menyewakan gedung $M \& R$ yaitu:

1. Uang muka dapat dikembalikan atau dialihkan untuk acara lainnya dengan dikenakan biaya administrasi.

2. Apabila calon Penyewa yang membatalkan Penyewaan Gedung lebih dari 5 (lima) bulan sebelum pelaksanaan acara, akan memperoleh pengembalian uang muka sebesar $75 \%$.

3. Apabila calon Penyewa yang membatalkan penyewaan gedung kurang dari 5 (lima) bulan sebelum pelaksanaan acara, tidak memperoleh pengembalian uang.

4. Calon Penyewa yang membatalkan acara dan telah melunasi seluruh biaya sewa gedung (100\%), akan memperoleh pengembalian biaya sebesar $25 \%$.

5. Apabila calon penyewa gedung tidak membatalkan penyewaan, tetapi di Open Date, maka harus mengikuti harga baru. Dan apabila Open Date dibatalkan akan dikenakan pemotongan 50\% dari DP (Down Payment), 5 (lima) bulan sebelum pelaksanaan acara.

6. Pembatalan harus disampaikan dengan surat resmi oleh pihak Pemesan disertai dengan Meterai 6000.

7. Pembatalan tidak boleh diwakilkan oleh pihak keluarga lain, dan proses pengembalian biaya pembatalan adalah 1 minggu setelah menandatangani surat pembatalan pihak Yang Bersangkutan ke pihak Management Gedung M\&R". ${ }^{34}$

Klausul tersebut dibuat oleh pihak penyewa gedung dan mengikat bagi siapapun pihak yang sepakat ingin mengikatkan dirinya untuk menyewakan Gedung M\&R tersebut. Klausul tersebut dapat dikategorikan sebagai Klausul Eksonerasi. Klausul Eksonerasi atau Klausul baku dapat di artikan "setiap aturan atau ketentuan dan syarat-syarat yang telah dipersiapkan dan ditetapkan terlebih dahulu secara sepihak oleh pelaku usaha yang dituangkan dalam suatu dokumen dan/atau perjanjian yang mengikat dan wajib dipatuhi oleh konsumen". ${ }^{35}$ Dalam perjanjian sewa menyewa, pihak yang menyewakan berupaya untuk membatasi atau menghilangkan kewajibannya dengan membuat ketentuan

\author{
${ }^{29}$ Pasal 1551 KUHPerdata \\ ${ }^{30}$ Pasal 1550 ayat (2) \\ ${ }^{31}$ Subekti,“Hukum Perjanjian”, Cetakan-20 (Jakarta :Intermasa) hlm.90.2004 \\ ${ }^{32}$ Pasal 1550 ayat (3) \\ ${ }^{33}$ Op.Cit Subekti h.92 \\ ${ }^{34}$ Perjanjian Syarat Ketentuan Pemakaian Gedung M\&R \\ ${ }^{35}$ Lihat Pasal 1 angka 10 Undang-undang No.8 Tahun 1999 Tentang Perlindungan Konsumen
}


khusus tentang sewa tersebut. Menurut peraturan ini, penyewa tidak bertanggung jawab atas beban yang timbul baik berupa biaya maupun kerugian yang akan timbul. ${ }^{36}$ Klausul Baku dalam sewa menyewa dipakai melindungi kepentingan pemilik, agar barang yang disewakan tidak dirusak oleh penyewa. Selain itu, hal ini tidak akan menimbulkan biaya sewa yang hanya ditanggung oleh pemiliknya. ${ }^{37}$

Dalam pemenuhan hak dan kewajiban yang diakibatkan adanya pandemi covid-19 yang membuat tidak dapat terlaksananya acara resepsi pernikahan ini pihak pemilik Gedung M\&R melakukan renegosiasi kepada pihak yang menyewa gedung tersebut dengan menawarkan penundaan pelaksanaan resepsi pernikahan ke tahun berikutnya namun jika para pihak yang menyewa tetap melakukan pembatalan dan mengadakan pernikahan sesuai dengan aturan yang ditetapkan oleh pemerintah maka pihak gedung M\&R tetap mengikuti aturan klausul pembatalan tersebut serta adanya renegosiasi mengenai persenan yang harus dikembalikan terhadap uang muka yang telah di bayarkan.

\section{SIMPULAN}

Pandemi Covid-19 dapat digolongkan sebagai keadaan kahar namun dengan adanya pandemi ini tidak secara langsung dapat menjadi alasan pembatalan penyewaan gedung pernikahan di Gedung M\&R karena pandemi covid-19 ini digolongkan ke dalam keadaan kahar yang bersifat sementara maka perjanjian sewa gedung di M\&R dapat ditangguhkan untuk sementara waktu dan penyewaan tersebut dapat dilakukan kembali jika pandemi covid-19 telah berakhir.

Dalam pemenuhan hak dan kewajiban pihak yang menyewakan dan penyewa gedung M\&R dapat melakukan negosiasi kembali dengan mengatur ulang hal-hal yang dapat melindungi para pihak karena adanya keadaan pandemi covid-19 ini dengan tetap berdasar pada asas kebebasan berperjanjian, asas keadilan dan asas proporsionalitas seperti dalam hal pengembalian uang sewa jika terjadi pembatalan atau penundaan pelaksanaan pernikahan yang diadakan di gedung M\&R. Maka saran yang penulis berikan bagi para pihak yang akan melakukan suatu perjanjian sewa menyewa yaitu agar tetliti dalam memeriksa setiap klausula pada perjanjian dengan berdasarkan pada asas kebebasan berperjanjian, dan dengan adanya pandemi covid-19 agar para pihak dapat terlindungi kepentingannya yaitu para pihak dapat memastikan pemilik gedung untuk dapat melakukan kewajiban perjanjiantual yaitu dengan melakukan renegosiasi perjanjian dengan mengatur kembali hal-hal yang harus dicantumkan dalam suatu perjanjian terlebih dengan adanya keadaa baru seperti pandemi covid-19 ini dengan tetap berlandaskan pada asas kebebasan berperjanjian, itikad baik serta asas keadlian.

\section{DAFTAR PUSTAKA}

\section{Buku}

Augustinus S "HUKUM BISNIS: Sebuah Pemahaman Integratif antara Hukum dan Praktik Bisnis", Depok: PT RAJAGRAFINDO PERSADA.2018

Budiman N.P.D S, , "Hukum Perjanjian \& Penyelesaian Sengketa Dari Perspektif Sekretaris", (Jakarta: PT RAJAGRAFINDO PERSADA). 2005

Subekti, "Hukum Perjanjian", Cetakan-20 (Jakarta: Intermasa). 2004

Suharnoko, Hukum Perjanjian: Teori dan Analisa Kasus (Jakarta : Kencana).2017

\section{Jurnal}

Agri Chairunisa IsradjuningtiasJurnal: Force Mejerure (Overmacht) dalam Hukum Perjanjian (Perjanjian) Indonesia, Fakultas Hukum Universitas Katholik Parahyangan. 2016

D.R,Buana , 'Analisis Perilaku Masyarakat Indonesia dalam Mengha dapi Pandemi Virus Corona (Covid-19) dan Kiat Menjaga Kesejahteraan Jiwa', salam jurnal sosial dan budaya Syar'I , Vol.7, 2020

Dewitasari, Y., \& Tuni, P. Akibat Hukum Terha dap Para Piha k dalam Perjanjian Apabila Terjadi Pembatalan Perjanjian. Fakultas Hukum Universitas Udayana. 2011

Dona B.K “Pandemi Covid-19 Apakah Keadaan kahar?”, Jurnal Rechts Vinding : Media Pembinaan Hukum Nasional. 2020

Hero Pandi, "Penyelesaian Ganti Rugi Karena Force Mejeure Dalam Kasus Jasa Pengangkutan", Fakultas Hukum Universitas Islam Malang.2019

Kaya, P. B. T. A., \& Dharmawan, N. K. S, Kajian Keadaan kahar Terkait Pemenuhan Prestasi Perjanjian Komersial Pasca Penetapan Covid-19 Sebagai Bencana Nasional. Kertha Semaya: Journal Ilmu Hukum.2020

Muljono, B. E., \& Sastradinata, D. NKeabsahn Keadaan kahar Dalam Perjanjian Di Masa Era Pandemi Covid19. Jurnal Humaniora: Jurnal Ilmu Sosial, Ekonomi dan Hukum. 2020

${ }^{36}$ Rondonuwu, R. C. (2018). Hak Dan Kewajiban Para PihaK Dalam Perjanjian Sewa Menyewa Menurut Pasal 1548 Kuhperdata. Lex Crimen, h.9

${ }^{37}$ Ibid h. 10 
Ramadhani,D.,Wien Sukarmini,dan Yuliana Yuli Pelatihan Membuat Surat Perjanjian Sewa-Menyewa Rumah Perjanjianan Di Keluraha n Tugu, Kota Depok, Jawa Barat, Fakultas Hukum, Universitas Pembangunan Nasional Veteran Jakarta.2019

Rondonuwu, R. C "Hak Dan Kewajiban Para Pihak Dalam Perjanjian Sewa Menyewa Menurut Pasal 1548 Kuhperdata". Lex Crimen.2018

Sani, A. "Tanggung Jawab Para Pihak Dalam Pelaksanaan Perjanjian Sewa Menyewa Mobil Pada Cv Mutiara Transportation Di Kota” TEGAL (Doctoral dissertation, Program Pasca Sarjana Universitas Diponegoro).2005

Wafa, K., Suseno, I., \& Prasetyawati, E. Klausa Keadaan Kahar Dalam Perjanjian Dan Pandemi Covid-19 Di Indonesia. Maleo Law Journal, 4(2).2020

Wibawa, P. P. A., \& Artadi, I. K. "Akibat hukum terhadap pemilik gedung atas terjadinya force majeure (keadaan memaksa).”Kertha Semaya: Journal Ilmu Hukum 2 No.6:

\section{Peraturan Perundang-undangan}

Kitab Undang-Undang Hukum Perdata

Republik Indonesia. Undang-undang Wabah Penyakit Menular, Undang-undang Nomor 4 tahun 1984, Lembaran Negara LN 1984/20; Dan Tambahan Lembaran Negara NO. 3273

Keputusan Presiden Republik Indonesia Nomor 12 Tahun 2020 Tentang Penetapan Bencana Non-Alam Penyebaran Corona Virus Disease 2019 (Covid-19) Sebagai Bencana Nasional

Peraturan Gubernur Jawa Barat Nomor 36 Tahun 2020 Tentang Pedoman Pembatasan Sosial Berskala Besar Dalam Penanggulangan Coronavirus Disease 2019 (Covid-19) Di Wilayah Provinsi Jawa Barat Wilayah Provinsi Jawa Barat

Republik Indonesia, Undang-undang No.8 Tahun 1999 Tentang Perlindungan Konsumen

\section{Naskah Internet}

Marcel Mariana (2020), Batal Resepsi Karena Wabah Virus Corona Pasangan Ini Bagi-bagi Makanan Catering Ke anak Yatim-Kami Ingin Semua Seha $t$ Walafiat https://sajiansedap.grid.id/read/102071598/batal-resepsi-karenawabah-virus-corona-pasangan-ini-bagi-bagi-makanan-catering-ke-anak-yatim-kami-ingin-semua-seha t-walafiat

Muhammad Yasin (2020), "Penyebaran Covid-19 ditetapkan sebagai bencana nasional" https://www.hukumonline.com/berita/baca/lt5e947d66e1254/penyebaran-covid-19-ditetapkan-sebagai-bencananasional/

P.N.H. Simanjuntak, 2007, Pokok-pokok Hukum Perdata Indonesia, Djambatan, Jakarta, Adriansyah (2020), "Pembatalan Perjanjian Karena Pandemi Covid-19 Keadaan kahar" https://www.propertynbank.com/pembatalan-perjanjian-karena-pandemi-covid-19-force-majeure/

\section{Lainnya}

Perjanjian Syarat Ketentuan Pemakaian Gedung M\&R 